\title{
Health and Educational Status of Rohingya Refugee Children in Bangladesh
}

\author{
Mahbub Alam Prodip ${ }^{1}$
}

\begin{abstract}
A large number of Muslims have migrated to Bangladesh as refugees from Myanmar since 1991. The government of Bangladesh initially welcomed and accommodated refugees in twenty-one camps in Cox's Bazar during the influxes in 1991-1992. Now, over 220,000 refugees, mostly drawn from the Rohingya ethnic group, are living in two primitive camps along the border, having fled the widespread forced labor and ethnic and religious persecution they received within Myanmar. Among the refugees living in the camps, children have been suffering from a variety of health problems including widespread malnutrition. This article explores the situation of Rohingya refugee children living in one of the camps with regard to their educational and health status. Key informant interviews using both primary and secondary sources of information were used to analyze the current situation. The study reveals that the health and educational status of Rohingya refugee children in Bangladesh may be an improvement over their life in Myanmar. However, gender discrimination is inherent in some of the programs providing health and education to Rohingya refugee children.
\end{abstract}

Keywords: Rohingya; refugee children; displacement; health; education; Bangladesh; Myanmar.

\section{Introduction}

The term Rohingya is used to distinguish an ethnic, linguistic and religious group who lived in the former Arakan State of Myanmar. Rohingya people are officially stateless and disowned by the Myanmar government, which argues that Rohingyas are not Myanmar citizens and that they came originally from Bangladesh (MSF, 2010; Ahmed, 2010). The forced migration of Rohingyas from Myanmar's Rakhine State (formerly known as Arakan) to Bangladesh is not a new issue in South and Southeast Asian migration history, as this refugee $^{2}$ flow has continued for nearly 40 years (Ullah, 2011). However, the issue has recently gained increasing attention from the international community and the regional governments involved (Lanjouw, Mortimer \& Bamforth, 2000). Deprived of a homeland, the Rohingyas have not only been maltreated by their country of origin but have also been denied protection by Bangladesh against violence, corruption, abuse, and poverty (Devitt, 2011).

Forced migration of Rohingya refugees was first seen in Bangladesh in 1978 and again in 1991-1992 (Smith, 1995). Almost 250,000 people migrated to Bangladesh during these two periods (Imran \& Mian, 2014). The government of Bangladesh received Rohingya refugees

\footnotetext{
${ }^{1}$ University of Rajshahi, Rajshahi, Bangladesh. Email: prodip.mahbub@yahoo.com

2 A refugee is defined as a person who: "owing to a well-founded fear of being persecuted for reasons of race, religion, nationality, membership of a particular social group or political opinion, is [living] outside the country of his nationality and is unable or, owing to such fear, is unwilling to avail himself of the protection of that country." (Convention Relating to the Status of Refugees, 1951, Art. 1 A.2.)
}

An earlier version of this paper was presented at the $4^{\text {th }}$ Regional Conference of the Mahidol Migration Center (MMC) at the Institute for Population and Social Research (IPSR), Mahidol University, Salaya, Thailand on June 28-30, 2016. 
with a great deal of sympathy and provided all forms of support including relief, temporary shelters, food, medical care and health, and sanitation affairs during the first influx in 1978. However, they decided that the refugees could not stay for a longer period and had to return Myanmar as soon as possible. In this context, the government of Bangladesh attempted a large-scale repatriation ${ }^{3}$ based on the Bangladesh Myanmar Memorandum of Understanding (MOU) in response to this refugee flow. As a result, the first repatriation began on a very limited scale on 22 September, 1992 (Abrar, 1994). However, the process of repatriation was not voluntary. ${ }^{4}$ Most of those who fled to Bangladesh did not get official status as refugees from the Bangladesh government (Feeny, 2001). Currently, only 32,000 Rohingyas have been recognized as refugees and are living in two camps, while 35,000 unrecognized refugees have taken shelter in makeshift sites. In addition, an estimated 300,000 undocumented Rohingya refugees are living in host communities (Zinnat, 2016). Among the refugees in the camps, more than 50\% are children, aged younger than 18 years. These are the most visible and vulnerable population in the camps.

\section{Objective and Methods}

This paper investigates the educational and health status situation of Rohingya refugee children living in Bangladesh, with specific attention to gender issues. The study is qualitative in nature and is based on primary and secondary data from a wide range of sources.

\section{Primary data}

Nayapara camp in Cox's Bazar was chosen as the study area as it is the larger of the two camps located there. Key informant interviews using an open-ended structured questionnaire and semi-structured interviews of Rohingya children were used to collect the primary data. The semi-structured interviews were conducted with 16 Rohingya refugee children (eight boys and eight girls) who were aged 8-16 at the time of the interview. Four parents of the refugee child respondents, two teachers of schools within the study site and two health officials were chosen for the key informant interviews. Data analysis was performed through quotation and statement analysis. The study obtained informed consent permission from respondents and preserved their privacy and anonymity. Letters (e.g. participant A, B, and C) are used in the paper rather than names of the participants, with a view to maintaining anonymity. ${ }^{5}$

\section{Secondary data}

\footnotetext{
${ }^{3}$ Repatriation means a way that refugees can return to their country of origin in safety and dignity, but the return must be voluntary (UNHCR, n.d.).

4 The repatriation program has been surrounded by much controversy and allegations as the Bangladesh government and UNHCR authorities used force and coercion to send Rohingya to Myanmar from the camps in Cox's Bazar. Rohingya refugees held demonstrations to protest against the repatriation, demanding a total halt to the process. Fifteen refugees died during the first repatriation in the camps in 1993. In 1997, 187 refugees from Nayapara camp were forcibly sent back to Myanmar by the security forces of Bangladesh. The police entered Nayapara camp and forced separated refugees from their families. Refugees of Nayapara camp fought back with canes, iron rods, and bows and arrows. In response, police used tear gas to control them. As a result, 20-25 people were injured, including policemen (Abrar, 1994; Feeny, 2001).

5 The letter A-H and I-P was used to indicate Rohingya refugee boys and girls respectively. The letter Q-X was used to recognize key informant respondents such as parents, school teachers, and health officers chronologically.
} 
Secondary data was collected from various sources, including books, journal articles, conference papers, reports of various NGOs and other organizations, UNHCR documents, and news and feature articles from contemporary newspapers.

\section{Rohingyas in Myanmar}

The Rohingya people live in the northern part of Rakhine State, which is a mountainous area that is separated from the rest of Myanmar. While Myanmar has almost 140 ethnic groups, Rohingyas are not officially recognized as an ethnic group (Nurul, 2004). The Myanmar government has imposed various strict restrictions on Rohingya people, such as denial of citizenship, forced labor, forced eviction, land confiscation and restrictions on freedom of movement. These are violations of human rights (Bridge Asia Japan, 2003). The government of Myanmar, through its military forces, Arakan nationalist groups, and Buddhist extremists continue widespread harassment of Rohingyas, even though the government elected in 2015 is working to improve the human rights situation in Myanmar (Ganguly \& Miliate, 2015). Almost 2.6 million Rohingya now dwell officially in the northern part of Rakhine State; but besides this official estimation it is believed that an additional million plus Rohingyas also reside there. Thus, the actual number of Rohingya in Myanmar is thought to be between four and five million (Ullah, 2011).

\section{Rohingyas Become Refugees: A Displacement Issue}

Over the last 50 years, the Rohingyas' political status has been changed dramatically. Until 1962, the Myanmar government recognized Rohingyas as an ethnic minority, providing them citizenship along with voting rights. In a few cases, Rohingyas were major participants in the Myanmar Parliament. But all of their rights ended in 1962, when the military took power and General $\mathrm{Ne}$ Win established an absolute military dictatorship. Under his dictatorship, a national effort began on December 12, 1977 to register citizens and exclude foreigners in a national census effort named "Operation Nagamin" (Dragon King) (Smith, 1995; Human Rights Watch (HRW), 2000). All citizens were registered by the military and Rohingyas were excluded from that census (Ullah, 2011). As a result, Rohingyas were forced to migrate to Bangladesh. Almost 200,000 Rohingyas fled Myanmar and sought asylum in Bangladesh by May 1978 - known as the "first major wave" of Rohingya migration (Coutts, 2005; Ullah, 2011).

In 1982, the Myanmar government passed a discriminatory law, called the Citizenship Act (South, 2005), which made Rohingyas stateless. This law was heavily criticized by human rights groups (Al-Mahmood, 2012). The "Central Body" of the Myanmar government introduced three types of colored cards called Citizens Scrutiny Cards (CSC) in 1989: pink cards for full citizens, blue cards for associate citizens and green cards for naturalized citizens. Rohingyas were not issued any CSC cards, with the Central Body arguing that Rohingyas do not qualify for any of these types of colored cards (Lewa, 2001; Uddin, 2012). Then a state-sponsored series of attacks of ethnic violence in 1991 pushed about 250,000 Rohingyas to Bangladesh, where they were given places in squalid, makeshift camps with little or no access to health care or education (Al-Mahmood, 2012; Ullah, 2011).

\section{Rohingya Refugees in Bangladesh}

Rohingyas have been isolated from the international community as well as from the Myanmar majority population for the last twenty years, which has led to an overall lack of support for this population. The separation has further led to a lack of education, spartan living conditions, lack of standard health and other social care, and limited opportunities for 
a productive future (Garcia \& Olson, 2008). In Myanmar, Rohingya people have become aliens in their own land, facing discrimination including forced labor, limited mobility, arbitrary taxation, repossession of land, and extortion in all spheres of life (Lowenstein, 2015). As described above, the Myanmar government's citizen registration policies forced the Rohingya of Arakan to enter Bangladesh in 1978 (Haque, 2013). Further, state-sponsored violence in 1991-1992 drove Rohingya refugees from the western part of Myanmar's Rakhine State to the south-east district of Cox's Bazar in Bangladesh (Imran \& Mian, 2014). Cox's Bazar is located near the border with Rakhine state in Myanmar, bounded by the Naf River. Besides those recognized as refugees by the Bangladesh government, a huge number of refugees are living illegally in Cox's Bazar, Bandarban, and the Chittagong Hill Tracts (Haque, 2012). The Bangladesh government initially accommodated Rohingyas in twentyone camps in the southeastern region in Cox's Bazar in Bangladesh during the influxes of 1991-1992 (Zinnat, 2016).

The treatment and status of the Rohingyas has become a controversial issue for Bangladesh. Bangladesh is not legally obliged to provide necessities for the refugees (Ahmed, 2010). Bangladesh is not a signatory party to the 1951 Refugee Convention or its 1967 Protocol, like other states in Asia. Nor is Bangladesh a party to the 1954 and 1961 Stateless Persons Conventions (Abrar, 2012). However, Bangladesh has often opened its door to welcome refugees on humanitarian grounds even if they had only poor facilities to offer (Amin, 2012). Rohingyas have faced threats of violence and extortion for many years. Most of them were sent to Myanmar in the name of "voluntary repatriation" against their will. Although involuntary repatriation has been reduced remarkably in recent years, Rohingyas still have faced aggression and violence created by the officials of their camps (Médecins Sans Frontières, 2002). The Bangladesh government has continuously refused to welcome any "new arrivals" of Rohingyas as refugees since the repatriation process started in 1992 under the auspices of the United Nations High Commissioner for Refugees (UNHCR) (Feeny, 2001). The last repatriation was enacted in 1997 by the Bangladesh government, in consultation with UNHCR. The government of Myanmar was supposed to receive 21,117 refugees under the repatriation process; however, Myanmar received only 7,535 refugees by April 1997 and consequently, the repatriation process stalled in 2005 (Parnini, Othman \& Ghazali, 2013; Uddin, 2012). Moreover, the Rohingya population continued to enter Bangladesh to escape persecution (Zinnat, 2016).

The government of Myanmar declared a state of emergency in Rakhine on June 2012 due to the communal clashes between the Muslim and the Buddhist communities (HRW, 2012). Rohingya activists claimed that almost 1,000 people were killed at this time, however, the government only admitted to 211 deaths. Significantly, more than 140,000 people were displaced, with 94\% being Muslims (O'Sullivan, 2013). More than 90,000 Rohingya refugees fled Myanmar to the Bangladesh border. However, the Bangladesh government denied shelter to Rohingya refugees and security forces turned back more than 660 Rohingya people, most of them children and women. While protesting that the country had already accommodated more than 400,000 Rohingya people in Cox's Bazar, Bangladesh for the first time refused to accommodate the Rohingya refugees (Imran \& Mian, 2014). They also banned the activities of three prominent international NGOs Médecins Sans Frontières (MSF), Action against Hunger (ACF), and Muslim Aid), who were providing assistance to Rohingyas in Cox's Bazar and surrounding areas in late July 2012 (HRW, 2012). In 2014, marriages between Bangladeshi and Rohingyas were banned by the government, arguing that marriage between Rohingyas and Bangladeshis would create social and cultural problems and force it to give citizenship to refugees ("Ban on marriage with Rohingya refugees", 2014). 
Bangladesh does not have any domestic or international law which can legalize the administrative procedure to look after refugee affairs or to guarantee the rights of asylum seekers (MSF, 2010). As a result, unquestionably the Bangladesh government has the right to refuse to accommodate the Rohingya refugees. The Refugee Relief and Repatriation Commissioner (RRRC) is the top official in charge in the camp (Feeny, 2001), with administrative responsibility vested in the Ministry of Food and Disaster Management.

UNHCR is the principal partner of the Bangladesh government taking responsibility to assure the protection of the Rohingyas in the camp (UNHCR, 2007). Based on the Memorandum of Understanding which was signed in 1993, the Bangladesh government welcomed UNHCR to work in Bangladesh (D'Costa, 2014). The Department of Public Health Engineering of the Bangladesh government controls the water supply, while UNHCR provides emergency services to the refugees in times of water crisis (Feeny, 2001). The government also welcomed the World Food Program along with other international organizations such as the International Federation of Red Cross and Red Crescent Societies (IRFC) and the Red Cross and the Red Crescent Society of Bangladesh (UNHCR, 2007). A number of services related to health and community development are provided by Technical Assistance Incorporated. Legal assistance to Rohingya and UNHCR mandate urban refugees is provided by the Bangladesh Legal Aid and Services Trust. The international NGO Médecins Sans Frontières (MSF) has been working within refugee camps to provide in-patient health care and to improve and continue sanitation in the camp (Feeny, 2001; UNHCR, 2007). The United Nations Population Fund (UNFPA) has also, through UNHCR, been involved with regards to reproductive health (UNHCR, 2007).

\section{Health and Educational Status of Rohingya Refugee Children}

Findings of the fieldwork are discussed below in two separate sections covering health and educational status.

\section{Health status within the camp}

MSF and Concern Bangladesh offer health care for the Rohingya refugee children in the camp through a range of medical assistance. These two organizations have operated different health programs including an expanded program of immunization, vitamin $\mathrm{A}$ and B supplements, de-worming campaigns and health education awareness sessions with the aim of ensuring good quality health care facilities to refugee children (Feeny, 2001). Nayapara Camp has four healthcare centers which provide facilities to Rohingya children: one is operated by the Bangladesh government and the other three by international NGOs such as MSF, Action against Hunger (ACF) and Handicap International. ${ }^{6}$ Children are offered primary health care by these healthcare centers. While earlier the children of the camp did not know anything about the health facilities, the situation has been changed recently since these health care centers are working to promote children's health in the Nayapara camp. ACF also provides semolina and nutrition packets for the children.

ACF gives me Suji (semolina) and nutrition packets regularly free of cost. I like these very much.

$$
\text { (In-depth interview, Rohingya refugee boy G). }
$$

\footnotetext{
${ }^{6}$ Key informant interviews, health officers.
} 
MSF and Concern Bangladesh offer quality medical assistance to Rohingya children. These NGOs works to reduce the vulnerability of fevers, respiratory infections, skin diseases, and diarrhea. MSF also improved sanitation conditions and increased medical access to children in the camp. To protect against death from malaria and fever, MSF has established an inpatient ward where children get health facilities (Concern Bangladesh, 2001).

We receive various health treatments from MSF such as for fever, influenza, headache, skin diseases and diarrhea. We do not need to pay money for receiving these services.

(In-depth interview, Rohingya refugee boy E).

MSF has developed a Community Health Workers service with a view to providing training at the community level in order to reduce their workload. The Rohingya boys and girls are treated equally by these NGOs while being provided primary health care services. In addition, Handicap International organizes physical exercise for the handicapped children in the Nayapara Camp.

Concern Bangladesh has undertaken different child oriented-preventive and curative health programs in the camp for all boys and girls. National Immunization Days are held in the camp to protect children from communicable diseases. The newborn babies are also vaccinated against BCG, polio, DPT, and measles in the camp (Feeny, 2001). The Rohingya children also receive Vitamins A and B, as well as health education access and awareness, from these two organizations (Feeny, 2001).

These services are in stark contrast with the situation of Rohingya people still living in Myanmar, who do not enjoy any kind of health facilities. Thus, although the residents of Nayapara camp live in a very restricted condition, they say that they are very happy to stay there.

\section{When I was in Myanmar I saw that Rohingya people including children did not receive any health facilities from the Myanmar government. Our children are given very basic and primary health treatment by the [Bangladesh] government and NGOs in the camp. \\ (In-depth interview, Rohingya parent R)}

However, Rohingya children's health is affected by the substandard conditions that they face in the camp, such as open sewers and substandard sanitation systems (UNHCR, 1999). The flows of open sewers are seen between the sheds in the camps, summoning insects including malaria-carrying mosquitoes. Children are often playing along the banks of trenches without awareness of the risk of malaria and of skin diseases. They also use the sewer for urination and defecation (Feeny, 2001). The sewers time and again overflow because of poor inhibition maintenance during the rainy season.

An additional issue is that the sanitation and bathhouses were built without considering gender: their location, which is a short distance from the residences, has exposed women and girls to unsafe conditions and a lack of privacy (Ullah, 2011). The substandard sanitation system, while it affects the health of all of the children, creates a more difficult situation for girls. Girls often feel diffident to use the latrines. 
The condition of sanitation is very poor. Space is very congested and dirty as well. More than 15 people use a single latrine.

(In-depth interview, Rohingya refugee girl K)

It is embarrassing to use the latrine while boys are also waiting outside to use them whenever necessary. Due to having a limited number of latrines, people often knock at the door while we are using the toilet. This situation is really bad for girls and it hampers girls' safety and privacy.

(In-depth interview, Rohingya refugee girl L)

The Rohingya children of Nayapara camp have also suffered from an extremely high prevalence of acute malnutrition or wasting, as indicated by low weight for height (Ullah, 2011). Some observers have reported that the food ration provided by the Bangladesh government is of very poor quality. In most cases, children only receive one meal per day (Feeny, 2001).

Sometimes we cannot take [eat] food two times a day. My mother cannot earn enough money to feed us properly. As a result, we have to depend on the government's ration. However, we get the bad smell and very small insects in the rice while cooking. In a few cases, we have been sick by eating the low quality food.

(In-depth interview, Rohingya refugee boy B).

The Concern Nutritional Survey (2001) found that more girls are affected by low weight for height than boys in the camp, and that acute malnutrition is significantly higher in femaleheaded households than male-headed households

There are other reasons why the girls have a more tenuous state of health than the boys in the camp. Early marriage and its consequences, such as teenage pregnancy, have an extensive impact on refugee girls' health. Parents think that spending money for their daughters is a worthless expenditure, since daughters live with their husband's family after marriage. Also, many parents intend to marry their daughters to local men to get economic advantages and to receive Bangladeshi citizenship (Feeny, 2001; Papri, 2017). As a result, they wish to marry off their daughters as soon as possible, and early marriages of girls are increasing among Rohingya refugees in Bangladesh (Danish Immigration Service, 2011).

Early marriage impacts these girls in three areas: dangers to health for both the young mother and the child; problems of social integration; and the risk of experiencing abuse within marriage. Refugee girls frequently experience giving birth at early ages (between age 12 and 18) which has severe negative effects on their health (Feeny, 2001). Ullah (2011) found that the average age of marriage and the average age of first pregnancy in the camp are 14 and 16 years respectively (Ullah, 2011).

When I was only 12 years old, my parents forced me to get married to my neighbor. I conceived at the age of 14 and delivered my baby underweight. I also faced many health consequences after giving birth.

(In-depth interview, Rohingya refugee girl K)

Girls may also have problems adapting to new family members after marriage. They are often physically and verbally abused by their husbands and other household members in their in-law's house (Feeny, 2001). It should be noted that early marriage is common among 
young girls in Bangladesh as well; a majority of women (77.7\%) get married before the age of 18 (Jisun, 2016; NIPORT, 2013). Thus, the issues discussed here are not confined to the refugee population.

\section{Educational status within the camp}

The refugee children have received formal educational opportunities in the camp since 1997; however, their entrance was restricted to the primary and kindergarten levels by the Bangladesh government (Feeny, 2001). After 2007, the government established secondary education for Rohingya children in the camps. At present, the education program for Rohingya refugee children is being continued and implemented by Research Training and Management International (RTMI). The total number of primary schools is 21 (11 schools in Nayapara and 10 in Kutupalong) and there are two secondary schools (one school in Nayapara and one school in Kutupalong). Both Bengali and Rohingya teachers offer education to children in the camp's schools (RohingyaRefugee BD, 2009). Education is free for all in the camp, and the students get free educational equipment such as books, writing paper, pens and pencils provided by the government and international organizations. Thus the Rohingya refugee children do not have to think about their educational costs.

I came here in 1992. Even though we do not have enough opportunities in the camp, our children have access to education at least. Our children get all educational equipment free of cost whereas education is banned for Rohingya community in Myanmar.

$$
\text { (In-depth interview, Rohingya Parent S). }
$$

After being displaced from Myanmar, the refugee children were given shelter to stay and continue their studies up to class eight. Over the years, the government and NGOs have established 11 schools in Nayapara camp, where more than 4,000 students receive an education. The number of teachers is 67, including supervisors. Students are enthusiastic to learn new things.

I have seen that children here are very happy. Although we have a few limitations, children of the refugee community at least get the basic education, which is totally impossible in Myanmar. We are very grateful to the government of Bangladesh for giving us shelter and education.

(In-depth interview, school teacher U)

To encourage Rohingya children to go to school regularly, the government provides one pack of biscuits during the school day regardless of gender. Offering such incentives has motivated refugee children to attend the school regularly.

I have observed that children come to school every day. Most of the refugee families are poor and cannot provide food to their children three times a day. As the government provides one pack of biscuits as tiffin, parents encouraged their children to attend the school every day.

(In-depth interview, school teacher V)

However, key informants who were interviewed for the study reported that the teachers of Nayapara camp do not always fulfill their responsibilities. For example, in some cases they 
are absent from class without giving any notice, and students wait for a long time in the school (Feeny, 2001). The study also found teachers talked on the phone during class time.

Our teachers do not come to class regularly. Even sometimes they leave the classroom during class time without any reason, or talk over phone in the class for a long time. It disrupts our attentiveness to class.

(In-depth interview, Rohingya refugee boy C).

The negligence of the teachers makes children more vulnerable in terms of education. However, the teachers of Nayapara camp explained their position from a different point of view. They said that because they are given very low incentives for their work, they have lost interest in teaching the students with full effort.

I do not get enough money at the end of the month. I cannot support my family with this limited money. Thus, I have to search for other opportunities to earn more money for my family expenditures.

(In-depth interview, school teacher V)

The statement of the teacher corresponds with reports from the students of the school of Nayapara camp. Although the teachers have reasons for their absences and their lack of dedication to their job, the result is that they are negligent of their students in the camp.

One of the major problems relating to Rohingya refugee children's education in the camp is high drop-out rates. Feeny (2001) found that drop-out rates of Rohingya refugee children were very high, at $22 \%$ from kindergarten to the end of primary school. While initially, a large proportion of students enrolled in the kindergarten level, as they are promoted to upper classes their number decreases gradually (Concern Bangladesh, 2001). A recent study by UNHCR (2016) suggested that the drop-out rates remains high in the camps in Cox's Bazar. Only $11 \%$ of Rohingya refugee children were promoted to secondary level or post primary level education (grades 6 and 7) while $82 \%$ of them were enrolled in primary school education (grades 1 through 5) (UNHCR, 2016). While there are a number of reasons for these high drop-out rates from the camp's school, the basic cause relates to the intention of earning money. Most of the male students, but also some females, give up their studies to search for work in and outside the camp. ${ }^{7}$

I could not complete primary education. I completed only class three. Due to having an economic crisis, I had to give up my study. I need to work every day.

(In-depth interview, Rohingya refugee girl P).

As mentioned above, many of the female students of the camp give up their studies for early marriage. Their parents want them to get married as soon as possible; in most cases, parents think that daughters are their liability. This thinking further leads to school drop-outs (Feeny, 2001).

In the last year, I have given my daughter to marry before completing her education. It was really difficult for me to bear her expenditure.

(In-depth interview, Rohingya Parent Q).

\footnotetext{
7 Interviews with key informants, 2016.
} 
Daughters are good for nothing. When I will be old, my son will take care of me. I do not want to spend more money for my daughters. As a result, I have already let marry two of my daughters before completing their education.

(In-depth interview, Rohingya Parent S).

In order to enhance girls' attendance in the schools, motivational meetings are sometimes organized with parents. However, the interviews of Rohingya refugee children revealed that some teachers also feel that girls do not need to pay attention to their education; they discouraged girls to come to class regularly and to study seriously. These teachers explained to girls that education is only for class eight which does not have practical implications for their future; thus, girls should concentrate on household activities seriously so that they can maintain the family after marriage. This opinion was also expressed by some of the girls who were interviewed.

\section{Conclusion}

The research has shown that residence in the Nayapara refugee camp in Bangladesh has both positive and negative effects on Rohingya refugee children's health and education. Rohingya children have obtained basic health care facilities and primary education regardless of gender. Boys and girls have received primary health care facilities along with curative and preventive healthcare capabilities. Education is free for all boys and girls, provided by the Bangladesh government, which has also offered a few motivational incentives in order to enhance children's attendance in the school.

However, children have suffered from the effects of open sewers and substandard sanitation in the camp and from malnutrition due to inadequate food rations. Due to negligence of teachers, the quality of the education received has been hampered. There are also some gender issues affecting the refugee children's health and education. Girls have often hesitated to use substandard sanitation, which was not constructed with any gender considerations. Girls also experience the detrimental health effects of early marriage and teenage pregnancy in the camp, although this is also common in Bangladesh society. The negligence of teachers toward girls indicated clear gender discrimination in education, even though most girls were admitted at kindergarten and primary levels. Although the government offers motivational programs to enhance girls' attendance, their number has been decreasing gradually when they were promoted to higher grades.

Despite these inadequacies found in the health and educational programs provided at the camp, we conclude that displacement has mostly created an improvement in children's health and education. Rohingya children are deprived of any opportunity for health and education in Myanmar, whereas the Rohingya refugee children in Bangladesh have received basic health services from the government and UNHCR. Moreover, the Rohingya people do not have any kinds of rights in Myanmar, and state-sponsored violence forced Rohingya people to flee to Bangladesh to save their lives. Although the Bangladesh government has limited capability to provide necessary protection to the Rohingya people, their children's health and educational status is still better in the camps than it was in Myanmar.

\section{References}


Abrar, C.R. (1994). Repatriation of Rohingya refugees. Retrieved from http://www.burmalibrary.org/docs/Abrar-repatriation.htm

Abrar, C. R. (2012, June 20). Opening doors to Rohingya. The New Age.

Ahmed, I. (2010). The plight of the stateless Rohingyas: Responses of the state, society $\mathcal{E}$ the international community. Dhaka: The University Press Ltd.

Al-Mahmood, S. Z. (2012, June 12). Burmese Rohingya refugees find little respite in Bangladesh. The Guardian. Retrieved from http://www.theguardian.com/globaldevelopment/2012/jun/29/Myanmar-rohingya-refugees-bangladesh

Amin, K. (2012, June 15). Dhaka rules out shelter for Rohingya refugees. Priyo. Retrieved from http://news.priyo.com/national/2012/06/15/dhaka-rules-out-shel-53558.html

Ban on marriage with Rohingya refugees. (2014, July 11). The Daily Star. Retrieved from http://www.thedailystar.net/ban-on-marriage-with-rohingya-refugees-32826

Bridge Asia Japan. (2003). Brief report on activities, April 2003. Maungdaw, Myanmar.

Concern Bangladesh. (2001). Annual Report 2000: Rohingya Refugee Programme, Cox's Bazar.

Concern Nutritional Survey. (2001). Sustainable development initiative network concern worldwide: Nepal. Nutrition Survey Report. Concern Worldwide.

Convention Relating to the Status of Refugees. (1951). Retrieved from http://www.unhcr.org/enus/3b66c2aa10

Coutts, E. (2005). The Rohingya refugee situation in Bangladesh. Retrieved from http://www.rnapress.com/data/itemfiles/9bcc51b07210277172cfaca50dd60ff6.pdf

Danish Immigration Service, (2011, May). Rohingya refugees in Bangladesh and Thailand: Fact finding mission to Bangladesh and Thailand. Retrieved from https://www.nyidanmark.dk/NR/rdonlyres/B08D8B44-5322-4C2F-960444F6C340167A/0/FactfindingrapportRohingya180411.pdf

Devitt, R. (2011, September). Burma, Bangladesh and the Rohingya: A failure to protect. Retrieved from http:/ / www.e-ir.info/2011/09/06/ burma-bangladesh-and-the-rohingya-a-failure-to-protect/

D'Costa, B. (2012, August). Rohingyas and the 'right to have rights'. The Daily Star Forum6(8). Retrieved from http://archive.thedailystar.net/forum/2012/August/rohingyas.htm

Feeny, T. (2001). Rohingya refugee children in Cox's Bazar, Bangladesh. A discussion document prepared for UNICEF Regional Office South Asia. Dhaka: UNICEF.

Ganguly, S. \& Miliate, B. (2015, October 14).Refugees and neighbors: Rohingya in Bangladesh, The Diplomat. Retrieved from http://thediplomat.com/2015/10/refugees-and-neighbors-rohingyain-bangladesh/

Garcia, S. \& Olson, C. (2008). Rohingya: Burma's forgotten minority. Refugees International. Retrieved from http://www.refworld.org/docid/494f53e72.html

Haque, E. (2013, July 2). Humanitarian vs. legal deals: human rights monitor Rohingya people. The Daily Star. Retrieved fromhttp:/ / www.thedailystar.net/beta2/news/humanitarian-vs-legal-deals/

Haque, S. (2012, September 16). Forced migration to mainstream: A study on Rohingyas refugees in Bangladesh. BD Today. Retrieved fromhttp://www.bdtoday.net/english/thisweekdetail/detail/31

Human Rights Watch (HRW). (2000, May 1). Burmese refugees in Bangladesh: Still no durable solution. Retrieved from https://www.hrw.org/report/2000/05/01/burmese-refugeesbangladesh/still-no-durable-solution

Human Rights Watch (HRW). (2012, August 22). Bangladesh: Assist, protect Rohingya refugees. Retrieved from https://www.hrw.org/news/2012/08/22/bangladesh-assist-protect-rohingya$\underline{\text { refugees }}$

Imran, H. F. A. \& Mian, M. N. (2014). The Rohingya refugees in Bangladesh: A vulnerable group in law and policy. Journal of Studies in Social Sciences 8(2): 226-253.

Lanjouw, S., Mortimer, G., \& Bamforth, V. (2000). Internal displacement in Burma. Disasters, 24(3):228.doi: 10.1111/1467-7717.00144

Lewa, C. (2009). North Arakan: an open prison for the Rohingya in Burma. Forced Migration Review 32:11-13.

Lowenstein, K. A. (2015). Persecution of the Rohingya Muslims: Is genocide occurring in Myanmar Rakhine state? A legal analysis. Fortify Rights. Retrieved from http:/ / www.fortifyrights.org/downloads/Yale_Persecution_of_the_Rohingya_October_2015. pdf 
Médecins Sans Frontières (MSF). (2010, February 18) Bangladesh: Violent crackdown fuels humanitarian crisis for unrecognized Rohingya refugees. Retrieved from http://www.doctorswithoutborders.org/news-stories/special-report/bangladesh-violentcrackdown-fuels-humanitarian-crisis-unrecognized

Nurul, I. (2006, October 5). Facts about the Rohingya Muslims of Arakan. Retrieved from http://www.rohingya.org/portal/index.php/learn-about-rohingya.html

O'Sullivan, K. (2013, June 22). The plight of refugee: The uncertain future of Rohingya refugees. The Fair Observer. Retrieved from http://www.fairobserver.com/article/uncertain-futurerohingya-refugees

Papri, J. (2017). Marriage an uncertain path to citizenship for Rohingya refugees in Bangladesh. Radio Free Asia. Retrieved from http://www.rfa.org/english/news/myanmar/rohingya-marriage01272017085033.html

Parnini, N. S., Othman, R. M., \& Ghazali, S. A. (2013). The Rohingya refugee crisis and BangladeshMyanmar relations.Asian and Pacific Migration Journal 22(1):133-146. doi: $\underline{10.1177 / 011719681302200107}$

Rohingya Refugee BD. (2009, October 26). Rohingya refugee education program is getting worse to worse through RTMI. [Blog post]. Retrieved from http://rohingyarefugeebgd.blogspot.com/2009/10/rohingya-refugee-education-program-is.html

Smith, M. (1995, December). The Muslim Rohingya of Burma. Paper presented at the Conference of Burma Centrum Nederland.

South, A. (2005). Mon nationalism and civil war in Burma: The golden Sheldrake. London: Routledge.

Uddin, N. (Ed.) (2012). To host or to hurt: Counter-narratives on Rohingya refugee issue in Bangladesh. Dhaka: Institute of Culture \& Development Research (ICDR),

Ullah, A. A. (2011). Rohingya refugees to Bangladesh: Historical exclusions and contemporary marginalization. Journal of Immigrant \& Refugee Studies 9:139-161. doi: $\underline{10.1080 / 15562948.2011 .567149}$

UNHCR. (n.d.). Voluntary repatriation. Retrieved from http://www.unhcr.org/voluntaryrepatriation-49c3646cfe.html

UNHCR. (1999, 1-31 March). Refugees from the Rakhine State of Myanmar in Bangladesh - Situation Report No.99.

UNHCR. (2007). Bangladesh: Analysis of gaps in the protection of Rohingya refugees. UNHCR. Retrieved from http:// www.unhcr.org/protect/PROTECTION/46fa1af32.pdf

UNHCR. (2016, 10 August). Education of refugees: Priority activities and requirements supporting enrolment and retention in 2016. Geneva: UNHCR. Retrieved from http:/ / reporting.unhcr.org/sites/default/files/UNHCR\%20Education\%2020160810.pdf

Zinnat, M. A. (2016, 18 June). 3 lakh Rohingyas staying illegally. The Daily Star. Retrieved fromhttp://www.thedailystar.net/frontpage/three-lakh-illegal-rohingyas-1241512 